\title{
Distant Fathers: Disjointed World of George Eliot
}

\author{
Tahira Jabeen (Corresponding author) \\ School of Foreign Languages, East China Normal University \\ 500 Dongchuan Road, Shanghai 200241, P.R. China. \\ Tel: 0086-13524231638 E-mail:wee4t@yahoo.com \\ Liu Naiyin \\ School of Foreign Languages, East China Normal University \\ 500 Dongchuan Road, Shanghai 200241, P.R. China \\ Tel: 0086-13361996995 E-mail: naiyinliu@hotmail.com
}

Received: 26-08-2013

doi:10.7575/aiac.ijalel.v.3n.1p.115
Accepted: 24-10-2013

Published: 01-01-2014

\begin{abstract}
The article discusses distant fathers in the novels of George Eliot within the context of the nineteenth century. In the nineteenth-century Britain, the father's role is best defined by Nelson, "authority, guidance and financial support". (Natalie 2011, p.155) The article is devoted to explore the distant or absent fathers, which means no guidance, protection, and financial support to the children. The absence might be the consequences of many aspects relating to fathers. The father could be absent either physically or emotionally. The article argues that Eliot seeks and yearns for a perfect fatherhood by showing some shortcomings of the father and its effects on the lives of their children.
\end{abstract}

Keywords: George Eliot, distant fathers, nineteenth century

\section{Introduction}

In the nineteenth-century Britain, the father's role is best defined by Nelson, "authority, guidance and financial support." (McKnight 2011, p.155) So, the absence of the father means no guidance, protection and financial support to the children. In the nineteenth century, the distant and stern fathers emanated from the working-class and the middleclass men who had to spend long time away from the home and returned too tired to be involved in any activity, which John Tosh calls the "flight from domesticity". (Tosh 1999, p. 175) Most of the fathers in George Eliot's fiction, in Natalia B. Cole's words, are "absent, distant, ineffectual and tyrannical". (Cole 2011, p.33) These fathers either have no concern about the lives of their children, or they are absent physically. In the next section, the barren presence of the fathers will be discussed.

\subsection{Futile and Barren Presence: Thais Bede, Squire Cass and Mr. Transome's departed existence}

This section discloses the reasons and consequences of the barren presence of the fathers in George Eliot's novels. Active and passive fathers give to the domestic life a different color. In Silas Marner Squire Cass, in Adam Bede Thais Bede and in Felix Holt: The Radical Mr. Transome are the examples of barren presence who have no concern over what is going on in their children's lives.

In Silas Marner the titular character, as an affectionate father and Mr. Squire Cass as a reckless father are paralleled. Though Silas Marner, the fostering father of Eppie, is often juxtaposed with Godfrey Cass, the biological father of Eppie, Squire Cass, the father of Godfrey Cass can be compared with Silas Marner as a father in terms of attentive and responsible fathers.

In Silas Marner, the behavior of the fathers regarding their responsibilities towards their children represents two extremes of social class within the village of Raveleo. The double plot of the novel centers around two households, Marner's cottage by the stone-pits and the Cass manor, the Red House. The Cass family, headed by Squire Cass, is very prosperous in the village of Raveleo, "characterized by a popular myth of jollity and an opposed underlying actuality" (Mike 2003, p. 98) and there is no domestic affection in the hearth. Squire Cass is 'the greatest man in Raveleo', who "kept his sons in idleness". (SM p. 32) He is a landowner and does not earn the money from his own labor. His sons are idle too and involved in immoral activities. Dunstan, the elder son, spends his time in swapping animals and betting. Mr. Cass spoiles his sons not out of affection but out of negligence. The Cass family is very prosperous but cannot buy affections and values. On the other hand, Silas Marner, lives in a ramshackle cottage is the lowliest member of Raveleo society, and despite the fact that he is not the biological father of Eppie, proves himself a responsible father. This juxtaposition of fathers, belonging to different classes, shows the demoralization of the upper class and industriousness of the lower class. 
In Cass family, there is a gap between the father and the sons. The implacability of Mr. Squire Cass, the father makes Godfrey, the son hesitant to face him and tell about the death of Wildfire, the horse which he owns. The father claims, "I've been too good a father to you all' and 'I never threw a horse down in my life." (SM p.88) He, instead of being involved in the troubles of his son, complains about the current financial crises:

I am short o'cash as a roadside pauper. Why the country wouldn't have leg to stand on.

Prices 'ud run down like a jack and I should never get my arrears, not if I sold all fellow up.

(SM p.85)

He is in want of money and is shocked to learn about the death of the horse. He claims to be 'too good a father', but he is concerned about the loss only and does not enquire about his son Dunsey, who has been riding the horse, even after next two days when he does not return home. Thus, Mr. Squire Cass the "departed father" ( $S M$ p.182) remains aloof from the lives of his children and focuses only on his financial gains and losses. He fulfills the role of a provider but neglects his responsibilities as guide and protector.

Another distant father is Mr. Transome in Felix Holt, who is decrepit and has no participation in the household. Harold Transome, his son, after returning from Glasgow becomes the Radical but the father remains apart from the current domestic developments around him. He lives in a limited world of his own as Mrs. Transome says, "he will be like a distracted insect, and never know where to go, if you alter the track he has to walk in". ( $F H$ p.20) It is because of his reserved nature that in the whole story, there is no communication between the father and the son. When his son Harold comes home, he asks his mother about the father and goes to see him but there is no description of their meeting. Harold Transome also says about the father, "what a wreck poor father is! Paralysis, eh? Terribly shrunk and shaken — crawls among his books as usual, though." ( $F H$ p.17)

Thais Bede in Adam Bede is another example of distant father who does not show up in the story, and we learn from the conversation of the other characters that he is alcoholic. His absence from the home and his incomplete work to build a coffin makes his son Adam angry. Later, he is found dead under a willow tree.

All these distant fathers once have been good providers for their children. However, now they are aloof from their children's lives and because of their barren presence, their sons, Adam Bede, Godfrey Cass and Harold Transome become the father figures for their own fathers, and the filial duties are reversed. When Godfrey offers money to his father, he could not say anything but "staring at his son in amazement" because he is unable to guess in narrator's words, "what could have caused the inversion of filial duties". (SM p.50) Almost the same situation is present in Bede family where the father is absent because of his alcoholism and Adam becomes the care giver to the father. "I know there is duty to be done by my father, but it isn't my duty to encourage him in running headlong to ruin". ( $A B$ p.18) Once his father has been active, as Adam recalls the vanishing days when his father could build a wonderful pigeon house at Braxton parsonage or could give his son "an uncommon notion o' carpenting."( $A B$ p.46) Mr. Thais Bede, who dies because of alcoholism, is the burden on his family. "It is clear that Thais' loss is seen rather as a blessing than as an occasion of deep sorrow for the Bede family". (Barbara 2003, p.108) His death is rather a source of a sigh of comfort for the family. Mr. Irwin says, "Poor old Thais! I should have been glad for the load to have been taken off my friend's Adam's shoulders in a less painful way". ( $A B$ p.70)

The three fathers discussed above are distant fathers parted from the lives of their children. In these families, the presence of the mothers, to some extent fills the gap created by the aloofness of the fathers. In the nineteenth-century "mothers were to be relied upon for personal care and emotional". (Davidoff \& Hall 2002, p.335) These three novels describe three different cases of parents. In Silas Marner, in Cass family, there is no mother at all and the home has no centrality. "The Red House was without the presence of a wife and a mother who is the fountain of wholesome love and fear in parlor and kitchen." In Cass family the father and sons "take their breakfast in the different times. There was no pleasant morning greeting between them; because "the sweet flower of courtesy is not growth of such homes as the Red House". (SM p.84-85) There is no maternal benevolence in the home so everyone lost the centrality and "the hearth has no smiles". (SM p.81) The daughter-in-law to be is expected to be "a fine change" and she "would be a saving to old Squire". (SM p.33) Godfrey also attracted to "neatness, purity and liberal orderliness of the Lammeter Household".(SM p.81) And after fifteen years of gap in the story of the novel, much has changed in the 'dark wainscoted parlour' and 'wifeless reign of old Squire Cass.' Nancy, the wife of Godfrey Cass brings "into the Red house the habits of filial reverence and preserved sacredly in a place of honor these relics of her husband's departed father". (SM p.182) As a daughter she brings reverence for the father and the family gets integration and centrality because of a mother figure.

In Felix Holt and Adam Bede Eliot represent strong mothers as compared to fathers. These mothers try to make the decision for their future instead of fathers whose presence is barren in both novels. In Felix Holt Mrs. Transome who manages the Transome estate, dominates her husband. The son, Harold and his mother often discuss the political situation and because of the egoistic nature, the mother wants her son to act according to her advice, but she becomes disappointed when she finds that her son became the Radical. The narrator points out that Harold left her when he was a boy; she perhaps indulged in the dream that he would come back a boy. ( $F H$ p.108) She tries to keep her hold on the private sphere as well as on the public sphere by dictating her son. She is shocked when he takes the rein of the estate in his hand and announces to stand for parliament election as a Radical candidate by breaking the tradition with family politics.

In Adam Bede and Felix Holt, there are powerful mothers, but they have different approaches to deal with their sons. Mrs. Transome in Felix Holt wants her son to consult her in everything while Lisbeth Bede in Adam Bede, though a 
vigorous old woman, she is aware of his sons' feelings and helps them to achieve their goals. Lisbeth Bede takes care of her husband and worries about his alcoholism. On the other hand, Mrs. Transome has no concern for her husband, who 'paused in his work and shrank like a timed animal looked at in a cage where flight is impossible' whenever his wife "appears in the doorway". ( $F H$ p.100) But this attitude of hers is not supported by the writer. She changes in through the time. When Harold comes back he does not pay attention to her advices. Her despair over her changing situation deepens when Harold treats her insensitively.

Mrs. Transome was forced from centre to periphery, from dream of self to the feeling for others. In this way, she shrank, her vision extended and she attained to a significant stage of growth in her character. (Dalal 2006, p.74)

It is Mr. Transome's senility, which makes Mrs. Transome to manage and head the Transome estate, during her son's absence. The father's "diminished masculinity and authority" (Cole 2011, p.172) restricted him to his library and playing with his grandson, Harry. His activities are described by the narrator:

There was Old Mr. Transome with a cord around his waist, playing a very poor-paced horse for a black-maned little boy about three years old, who was urging him on with loud encouraging noises and occasional thumps from a stick. (FH p.128)

According to Natalie, the imagery of "poor-paced horse" shows the submission and weakness. (Cole 2011, p.172) It is his own weakness that the mother assumes the father's economical role and continues using her authority to shape the son's political career. It is the son Harold, who decides to fulfill the father's role of authority, which his father has lost long ago.

The motherless sons of Squire Cass are made idle by their father. Though Mr. Thais Bede and Mr. Transome once have been active and did a lot for their children, eventually they are withdrawn from the mainstream of the home. Mr. Transome has no more roles in his son's political life, and the mother is too egoistic to be followed by the son. Now Mr. Transome's 'being like a distracted insect' in his wife's remarks and his "crawling among books" in Harold Words and "a timid animal in a cage" also show his escapism from the outer life which he cannot face. It is disclosed when Harold finds his origin as son of Mr. Jerym, the lawyer of family estate. Mr. Transome, in other words, has no ability to manage his home and be an empire of the household loses his masculine pride and thus could not fulfill the norms of masculinity, which were set by the society of the time. In John Tosh words:

To establish a home, to protect it, to provide for it, to control it, and to train its young aspirants to manhood, have usually been essential to a man's good standing with his peers. Masculinity, after all, was essentially about being master of one's own house.....indeed rule as 'father' embodied the primary meaning of term 'patriarchy'.(Tosh.1999. 8)

Thus, George Eliot's homes are not perfect without a benevolent mother and responsible father. Lisbeth Bede in Adam Bede proves herself an impeccable mother, but the home still needs the father's involvement. In Felix Holt, the decrepit father and authoritative mother make the scene even worse. In Silas Marner, the father neglects his role of the guide and the protector and home has no centrality without a mother or mother figure.

These inactive and distant fathers belong to different social classes by which George Eliot highlights the upset resulted by the absence of any authority. To bring forth this upset she operates with law of consequences in Silas Marner, where father after two generations reach at the point where they are 'almost as helpless as an uprooted tree'. As the result this family tree stops growing further when Eppie rejects her biological father.

Mr. Transome's account occupies a small portion in the whole story of Felix Holt, where 'Radicalism' demands a proactive struggle for the political change. The withdrawnness of Mr. Transome from the world around him shows loosing Transomes' hold from the political power. This declination of Transomes later comes obvious when Harold Transome's true identity is revealed. He stands for the Radicalism but his "snobbish opportunism" and using unfair means to win elections contrasts Felix Holt's honesty and "genuine political significance". (Pinion. 1981, p.156-7) Eliot stresses through Transome's story that for the political reform, power should not be given to dishonest and ignorant men. Mr. Transome's inactiveness and his barren presence leave no way to maintain Transome state. It goes to Holts where Felix Holt makes the 'Radicalism', unlike Harold, not a career but a cause to bring reformation. His address shows the realization of the lack of the parental authority on the whole, "there is low sense of parental duties in the nation at large." (FH p. 145)

In Adam Bede by showing the aloofness of father Eliot emphasizes on the sense of duty. Thais Bede, the father, losses respectability as well as authority because of negligence of his duties and become a burdensome weight by embarrassing the family with his drunkenness. ( $A B$ p.47) Adam takes the place of an authorial figure, who has a strong sense of duty towards his brother and mother, as Dinah's says, "Adam is like the patriarch Joseph, for his great skill and knowledge and the kindness he shows to his brother and parents." ( $A B$ p.87)

By these inactive fathers Eliot brings forth the damage done by the absence of any authority or father figure with in the family as well as on the broader level of society. For this purpose, she operates with the law of consequences in Silas Marner, shows the supremacy of good over evil in Felix Holt and more importantly the sense of duty as a crucial element for the betterment of the society in Adam Bede.

In George Eliot novels, there are some children who are independent and do not have the guide and protection of the father. The next section is about these children and will describe their situation without a father or father figure. 


\subsection{Dorothea and Lydgate: The Independent and Self-determining World of Middlemarch}

In the nineteenth-century father had the roles of guidance, protecting and providing for his children. This section will deal with the children who do not have fathers to guide and protect them. They are independent and face many hardships to reach at the maturity to take right decisions for them.

In George Eliot's novels, we can find different cases of fathers in relation to their roles. In The Mill on the Floss, Mr. Tulliver fails to give his children a bright future because of his own shortsightedness, but Mr. Wakem, the father of Philip having a practical and professional approach for his son's future proves himself a true guardian for his son. Silas Marner in Silas Marner proves himself a loving father and nurturer, and grows up the parentless Eppie. There are passive fathers, i.e. Mr. Squire Cass in Silas Marner, Thais Bede in Adam Bede and Mr. Transome in Felix Holt: The Radical who remain aloof from the lives of their children. In Middlemarch, the protagonists' fathers die long before the opening of the story. They have to decide and determine their own future. The story of Middlemarch revolves around the lives of Dorothea Brooke and Lydgate, who being independent, take decisions for themselves and suffer due to their own weaknesses and eventually reach to the stage of self-realization. They both want to shape historical change in the direction of enlightenment but having no guidance they come across to many hardships. Their struggles to fulfill their aims without any guardian is shown in the comments of the narrator, 'a social life which seemed nothing but a labyrinth of petty courses, a walled-in maze of small paths that led no whither, the outcome was sure to strike others as at once exaggeration and inconsistency. ( $M$ p.13) The use of 'labyrinth' and 'maze' shows the complexities of the world in which they live without any guiding signs towards their destinations.

Dodrothea Brooke is a passionate and zealous lady who wants to fulfill her aims despite of the social restrictions. In the prelude, she is regarded as Saint Theresa of the Victorian age. She wants an "epic life" and wants to contribute to the society where "women were expected to have weak opinion". ( $M$ p.7) So, to fulfill her aim, she yearns for an authoritative and absolute hand to assist her. Her vehement nature makes her "impatience of her uncle's talk or his way of 'letting things be' on his estate". She needs an authority which can approve her intellectuality. Her uncle Mr. Brooke who is her guardian too, fails to provide such an authority and cannot even acknowledge her ambitions. Knoepflmacher judges Mr. Brook in these words:

It is Mr. Brooke's failure to provide for nourishment of a different sort which, I think, lends him his importance. As we shall soon see, George Eliot actually holds Mr. Brooke responsible for Dorothea's plight. Totally incapable of perceiving any pattern or design in human events, he fails to provide the hungry imagination of his older niece with that large vision of relations which she desperately needs and desires in order to live in an intelligible universe. As impotent in rescuing a poacher from a death sentence as he is in rescuing Dorothea from her self-willed martyrdom as Casaubon's wife, Mr. Brooke lacks authority. Mr. Brooke cannot furnish his niece with the mental and emotional provisions she requires. Mired in a confusing present, he forces Dorothea to turn to Casaubon as her provider and thus causes her to become mired in a dead and destructive past. (Knoepflmacher 1975, p.56)

Thus Dorothea's uncle, Mr. Brook proves to be a shallow person as guardian to his niece. So, when she meets Mr. Casaubon, she is attracted to him because of his intellectuality. Dorothea, though well-educated, still she is very naïve to judge people and unaware of the complications of the outer world.

Dorothea's decision to marry Mr. Casaubon also leaves other people of Middlemarch in surprise. When Sir James Chettam tells Mrs. Cadawallader about Dorothea's decision, she calls it 'horrible'. And for her Mr. Casaubon is "no better than a mummy... who has one foot in the grave". Everyone is talking about ill-fitted and inappropriate marriage in opposing metaphors, like: Casaubon as a dry, old and Dorothea as a young blooming girl. She regards Dorothea's age not fitting to take a decision like this and this time her guardian should have his role. "Brooke ought not to allow it: he should insist on its being put off till she is of age. She would think better of it then. What is a guardian for?" In Sir James views it is useless to expect any better solution from Mr. Brooke, the guardian of Dorothea. He says, "As if you could ever squeeze a resolution out of Brooke!” ( $M$ p.47) The writer also highlights the efforts of stopping this marriage by Sir James and the dysfunctional guardian in the beginning of chapter 8 in these words:

Oh, rescue her! I am her brother now,

And you her father. Every gentle maid

Should have a guardian in each gentleman. (M p.55)

Sir James expresses his exasperation in these words, "she is too young to know what she likes. Her guardian ought to interfere. He ought not to allow the thing to be done in this headlong manner".( $M$ p.56) On the other hand, Mr. Brooke, the guardian of Dorothea, is an admirer of Mr. Casaubon and cannot see if this marriage is going to be ill matched. He is silly enough to think, "it was perhaps better for her to be early married to so sober a fellow as Casaubon". (M p.54) 
Dorothea Brooke possesses the ideal nature of Saint Theresa, but the existing social phenomenon restricted her to exert her own ambitions and play her role to change the society. She wants to do something recognizable like building cottages for the poor and founding a school. In this regard, for the approval of her proposals, she needs an authority in the form of a father or father figure. The authority, which has been provided by her parents who are dead now, can shape her life and help to fulfill her aims. In the confusing world of Middlemarch, she finds Mr. Casaubon the appropriate person who can understand her aims and can assist her to fulfill them because in the patriarchal society of the nineteenth century, women were seen having no vision and weak opinions. In Patricia's views, Dorothea submerged in the father figure to be acknowledged by the others. "Dorothea mistakenly believes her truest path towards fulfillment lies in committing herself to a father figure". ( Patricia 1990, p.42.)

She has always been anxious to have a father who can guide but her uncle Mr. Brooke failed to provide her such authority because of his own shortcomings and ...thus the only solution available to her is to marry someone who can be appropriate to her wishes. For her, marriage lies in the devotion to find an authority or a father figure. She says, "The really delightful marriage must be that where your husband was a sort of father and even could teach you even Hebrew if you wish it."' $(M$ p.8) She was impressed by the intellectuality of Mr. Casaubon and through him; she wanted to serve humanity. She felt her energies and capabilities insufficient because she is not confident about her plans to build houses for poor and founding a school. Later, it is proven that Mr. Casaubon's intellectuality is just shallow, and he cannot write a book which he claimed to write. As Patricia says:

In Middlemarch Casaubon's intellectual and emotional aridity underscores the lack of strong father figures in the community at large. No Knightly exists to endow the community with a sense of authority on which it may depend. (Patricia 1990, p.136)

Dorothea seeks this authority from her uncle Mr. Brook but being distracted and disappointed; she turns to Mr. Casaubon but she is again embarrassed and shocked totally to find no authority and guide to fulfill her aims.

Dorothea's shortcoming to judge him made all other people astonished but her own happiness is shown in narrator words as "child like reclining in the lap of divine consciousness". ( $M$ p.36) The metaphor of child explains further that she is not having enough maturity to take a big decision like this. She was possessed with the sense that an ideal life is opened to her. Her decision made her uncle and sister Cilia surprised. Celia, who already has expressed her disliking for Mr. Casaubon, could not believe at first about the engagement. Dorothea calls Celia 'commonest mind' when Celia points out some irritating habits of Mr. Casaubon. But the 'commonest mind' ironically came true to Dorothea's understandings and Celia's comment 'commonest minds must be rather useful' became the reality.

Her decision to marry Casaubon is to have an authority and strength but her decision to marry with Will Lidsaw is to complete her personality. Her sufferings are because of her immature decisions and her day dreaming about an ideal life gives her an experience to see life realistically. Casaubon wants her to be a submissive wife, but she refused to act accordingly because she wants herself to be defined.

Lydgate is another example of independent youth, who suffers because of his own weaknesses and inability to make a decision contemplatively. As D.S. Dalal says, "he came to be entangled in the ordinary affairs of life and unwittingly lost sight of his youthful vision." (Dalal. 2006, p.81) Having no authority and father, he "was still in making and there were both virtues and faults capable of shrinking and expanding". ( $M$ p.124)

About his early life and his ambitions and aims the narrators tells, "he was one of the rarer lads who make up their minds that there is something particular in life which they would like to do for its own sake, and not because their fathers did it".( $(M$ p.118) His independence from any patriarchy and authority is proved in his professional enthusiasm and his "youthful belief in his bread winning work". (M p.120)

Lydgate's spot of commonness lay in the complexion of his prejudices, which, in spite of noble intentions and sympathy, were half of them such as are found in ordinary men of the world; that distinction on mind which belonged to his intellectual ardour, did not penetrate his feeling and judgment about furniture, women, or the desirability of its being known without his telling that he was better born than other country-surgeons. (M p.125)

This 'spots of commonness' leads him to be puppet in the hands of Blustrode and Rosamond. Lydgate as a doctor proved his potentials by his cure of Mrs. Bulstrode, Fred Vincy, Nancy Nash and Casaubon from their ailments. His enormous vision is clear in his manifesto of making a hospital which is 'special destination for fevers.' The hygienic condition, poor ventilation and polluted water of the period gave birth to infectious diseases. There was a group of Victorians who brought health reforms but it was not expanded till Middlemarch yet. (Furst 1993, p.354) He was interested in the nature of fevers and wanted to continue Bichat's (1771-1809), a French anatomist and physiologist work to know about the fundamental knowledge. $(M$ p.123) But he couldn't judge Middlemarch and has been treated as a stranger because he came from outside. Despite of his smartness in his field, he remains innocent about interlocking intrigues when he was to appoint chaplain for the hospital. Bulstrode directs that Mr. Tyke should be chosen to supersede Mr. Farebrother, who has so far attended to the patients' spiritual needs. Lydgate, trying to be "circumspect," replies, "as a medical man I could have no opinion on such a point," and says, "nothing to do with clerical disputes." ( $M$ p.130) Because of his individualism, he loses the support of people of Middlemarch. He is totally self-made man and is 
unaware of familial and communal obligations and focuses on his aim of medical reforms at any cost. He wants to be free from the entanglements of the social obligations but later gets frustrated. "Poor Lydgate! or shall I say, Poor Rosamond! Each lived in a world of which the other knew nothing”. (M p58)

Both Dorothea and Lydgate have unrealistic and idealistic idea of the marriage. Dorothea's ideal is a great soul while Lydgate wants little more beauty than an ornament. Their marriages fail due to misinterpretation and false expectations from their partners. Both fight for the noble cause, but they do not have any guidance or authority to show the right way to deal with their objectives. They have the talent but they need proper insight to fight with hardships and complication which lay on their ways:

Each of those Shining Ones had to walk on the earth among neighbours who perhaps thought much more of his gait and his garments than of anything which was to give him a title to everlasting fame: each of them had his little local personal history sprinkled with small temptations and sordid cares, which made the retarding friction of his course toward final companionship with the immortals. (M p.175-6).

They both need the assistance to reach at their destinations but with great caution from 'temptations and sordid cares' with avoiding from them totally. They faced problems because of their own weaknesses. The whole social phenomenon served as a patriarchy to which they need to fight to reach at their aims. The ill matched marriages of them took them out from their illusions to the path of self-realization and to the real world. They are best explained in the narrators' words, "Reformers, martyrs, revolutionists are never fighting against evil only; they are also placing themselves in opposition to good" ( $M$ p.365). Finally, Lydgate gains the excellent practice, and "he had done what he once meant to do". ( $M$ p.685) Dorothea's acts were just 'mixed result of noble and young impulse' but what she has done is an example of living 'Dorotheas'. To reach at the level of maturity, they paid the price by sufferings. Dorothea and Lydgate's surrogate fathers do not take their fatherly duties seriously and disappoint their children "with emotional distance, arbitrary exercises of authority weak guidance or no guidance at all, and deny needed financial support". (Cole 2011, p.175) Eliot shows that when authority is denied the children go through many hardships to reach at the goals which could be accessible if they could have provided the fatherly guidance.

There is another father who cannot claim his child and thus remains in the state of denial for fifteen years. The next section will deal with this case of the father represented by George Eliot.

\title{
1.3 Denial and Striving for Being Father: Godfrey Cass in Silas Marner
}

\author{
"A child, more than all other gifts \\ That earth can offer to declining man, \\ Brings hope with it, and forward-looking thoughts." \\ -William Wordsworth
}

These lines of Wordsworth, used as the epigraph in Silas Marner, show that Eliot considers child to bring out a feckless man from spiritual desolation and dejection to the life full of hope and delight.

In the first two parts of this chapter absence of fathers and impact of it on the children is shown in the George Eliot's novels. This part will show a father who has been distractive and inattentive to his daughter for the fifteen years and now wants to claim her. The other absent fathers discussed above are not entirely absent. They somehow or the other are present and make efforts for their children in their past, before the opening of the stories. Their presence can be seen in their children, e.g. Adam Bede is made a carpenter by his father. His father helps him to be able to earn his living and be a provider in his future. Mr. Squire Cass in Silas Marner, though neglects his responsibility as a guide, he is well provider for his sons. Mr. Transome in Felix Holt manages to educate his son and sends him for higher education.

In Silas Marner, the paralleled but interlocking stories of Silas Marner and Godfrey Cass reflect that how great is having a child far a father. The both stories are interconnected by the child Eppie, whose biological father does not claim her to be his child, while Silas Marner adopts her and she becomes the centre of his life.

The biological father, Godfrey, to whom the child comes at the New Year Eve, does not have courage to claim his own child while the same child becomes the God's gift to Silas. Godfrey plays with the chance and wants to marry Nancy despite of his secret marriage with Molly, the mother of the child. He thinks that his confession can make his life unhappy. When he sees his own child in the arms of Silas Marner, he "with white lips and trembling"( $S M$ p139) is speechless and tries to hide his embarrassment. He is horrifyingly cruel to desire that Molly "might not be dead"( $S M$ p.139). His high status in the society does not allow him to confess that Molly was his wife and he is the father of the child. He is "a man whose happiness hangs in duplicity"(SM p.140) and he plays with chance and being incapable of action just wait for the consequences, "hoping for some unforeseen turn of fortune, some favourable chance which would save him from unpleasant consequences". (SM p.126) He hopes that if Molly has died then, Dunstan, his brother who blackmailed him about his secret marriage, cannot do any harm. At that time, there was no "active inquiry and registry of their marriage". (SM p.145) So the current system also provides him an escape to claiming his child and doing fatherly duties. His denial of his own child reflects the moral degradation of the upper class of Raveleo. He is divided because being the biological father of the child he does care for it. 
The wide-open blue eyes looked up at Godfrey's without any uneasiness or sign of recognition: the child could make no visible [or] audible claim on its father; and the father felt a strange mixture of feelings, a conflict of regret and joy... when the blue eyes turned away from him slowly, and fixed themselves on the weaver's queer face. (SM p.144)

He feels the child's cry "as if some fibre were drawn tight within him". (SM p.141) He gives Silas half-a- guinea for the clothes for the child. His disclamation of his daughter proved to be a generation breaker because later he could not have children from his second wife Nancy. George Eliot shows the law of the consequences in Silas Marner, firstly, Godfrey becomes the victim of his own weaknesses and secondly, Silas's gold stolen by Dunstan Cass came back in the form of the second Cass's daughter in his home, "it seemed as if there was a gold on the floor in front of the hearth". (SM p.135) His weakness lies in his timidity and moral courage and his marriage to Nancy Lammeter is proved barren.

The interlocking plots of Silas Marner show the social divisions but there is interconnection which has crucial importance for the father's role. Silas Marner the titular character is uplifted, while Godfrey Cass diminished as a father. "Godfrey, who has succumbed to his temptation, spends his life doing penance for his youthful wrong-doing". (Cohen 1983, p.414)

After fifteen-year gap in the novel, we see the Godfrey is desperate without a child. Now he is in striving to have a child and seeing his childlessness as retribution. He confessed his sin to his wife and wishes to adopt his own daughter, Eppie. For this purpose, they both go to Silas's home to discuss the matter. The debate between the biological father and nurturing father which is called the 'trail-scene' by Davis Carrol in George Eliot and the Conflict of Interpretations reflects that being a father seeks some sacrifices. (Carrol 1992, p.150) "It's my duty, Marner, to own Eppie as my child, and provide for her. She's my own child; her mother was my wife. I've a natural claim on her that must stand before every other". (SM p.224)

His assertion of the claim to have Eppie is fully rejected by Silas. Silas, who before fifteen years was feeble and distressing, now stands in front of Godfrey the son of a land owner. This strength and confidence are given to him by his fatherly devotion, and Eppie's love for him. Godfrey does not know that "Silas would rather part with his life than with Eppie". (SM p.188) Now he can challenge Godfrey. "Then, sir, why didn't you say so sixteen years ago, and claim her before I'd come to love her?" And later, "You're coming now and saying 'I'm her father' does not alter the feelings inside us. It's me she's been calling her father ever since she could say the word.” (SM p. 255)

Eppie also denies vehemently to going with Godfrey and wants to stay with Silas. Nancy also tries to make Eppie to decide in the favor of her biological father. "What you say is natural, my dear child- it's natural you should cling to those who've brought you up,' she said gently; "but there's a duty you owe to your lawful father." (SM p.234) Later, Godfrey is even contradicted by his wife Nancy because she comes to know that Eppie's happiness is with her nurturing and dutiful father.

To adopt a child, because children of your own had been denied you, was to try and choose your lot in spite of Providence: the adopted child, she was convinced, would never turn out well, and would be a curse to those who had willfully and rebelliously sought what it was clear that, for some high reason, they were better without. (SM p.217)

He wants her to "make a lady of her; she is more fit of it than for a rough life".(SM p.201) He is proud to be part of upper class and of his wealth which can make Eppie to have a prosperous life than this rough life at the cottage of Silas. It is after sixteen years he revealed that Eppie must have a high standard of life.

His superiority does not mean anything for Silas because of his moral courage. So, Godfrey cannot escape from the consequences, so he decides to face his childlessness as a reward of his evil deeds. His plan to claim his child shows his redemption.

Godfrey Cass's redemption through some kind of moral turning is equally laden with ambiguities. His redemption comes through acknowledging past sins of commission and omission - not only his unacknowledged wife and child but, even more, his failure to recognize the latter after the mother's death. Godfrey's redemptive confession to his wife of his past marriage and unacknowledged fatherhood is occasioned by the discovery of his criminal brother's corpse and the painfully accumulated gold stolen from Silas. (Fleishman 2010, p.108)

Godfrey embodies the victim of weakness and chance. After the death of his secret wife he avoids claim his child and thinks that the confession will not bring happiness in his life. He does not want to lose the chance to marry Nancy to maintain his high social status. But after the passage of time he comes to claim her daughter and promised to "be an intimate and benevolent father very different from the distant and tyrannical Cass senior". (Cole 2011, p.163) his promise shows not only the acceptance of his own rejection of duties but also realization of his own father's inactiveness as a father.

Komya Ayaka in her study relates the weaknesses of fathers to Eliot's own biographical details. Komya argues that Eliot makes fostering fathers successful rather than biological fathers because she had conflict with her own father. (Ayaka 2006, p.23) On the contrary, I argue that Eliot representation of father cannot be restricted to her own past 
because even her fictional fathers' success or failure is beyond their nature of relationship they have with children. By the representation of inactive, distant and absent father Eliot tries to show the weaknesses of fathers and their inability to guide the passionate youth of the time. Though she has a conflict with her father for some time, it is not only one factor which shaped her depiction of fathers as stern in her fiction. It is not Eliot alone who showed such fathers. Most of her contemporary writers were giving the same picture about the fatherhood in the nineteenth century. According to Valerie Sanders, "Victorian literature and life writing are full of stern fathers who are alien and other in their children's limited understanding". (Sanders 2009, p.187) Through these different aspects of fatherhood and showing the weaknesses and strengths of fathers, Eliot seeks and yearns for an ideal father because for her, the father is not to avoid and escape. Her presentation of fatherhood brings up the problems of patriarchy and authority of the father and aims to finding ways to refine it without shunning it.

\section{References}

Primary Sources

Eliot, G. (1994). Adam Bede. Penguin Books, England.

---- (1996). Daniel Deronda; London, Wordsworth Classics.

---- ( 1994). Middlemarch. Wordsworth Classics, London.

---- (1994). Silas Marner. Penguin Books, England.

---- (1994).The Mill on the Floss. Penguin Books, England.

\section{Secondary Sources}

Ayaka, K. (2006). “George Eliot’s Fantasy on Parenthood”. Liberal Studies, Meiji University.402 21-35.

Bailey, J. (2010). “A Very Sensible Man: Imagining Fatherhood in England c.1750-1830”. History, 95: 267-292.

Bissell, T. C. (1951). "Social Analysis in the Novels of George Eliot". ELH . 18 221-239.

Broughton, T. L. \& Helen, R. eds. (2007). Gender and Fatherhood in the Nineteenth Century. Palgrave Macmillan.

Carroll, B E. (1999). I Must Have My House in Order: The Victorian Fatherhood of John Shoebridge Williams. Journal of Family History. Vol. 24. 3 275-304.

Carroll, D. (1995). George Eliot: The Critical Heritage. London: Routledge.

Cohen, M. F. (1998). Professional Domesticity in the Victorian Novel: Women, Work and Home, Cambridge University Press.

Cole. N. B. (2011) “The Right 'O Things by my Own Fireside: Masculinity and Fatherhood in George Eliot's Fiction”. In Fathers in Victorian Fiction. ed. Natalie McKnight. Cambridge Scholars Publishing. 153-184.

Cotton, D. (1987). Social Figures: George Eliot, Social History and Literature Representations. University of Minnesota.

Eliot, G. (1855). Evangelical Teaching: Dr. Cumming." [online] Available: http://www.unz.org/Pub/EliotGeorge1908v03B-00265

Emerick, Ann Patricia. (1990). Irresistible Forces: Father/daughter Romance in $19^{\text {th }}$-Century Fiction. The University of Oklahoa, Norman.

George, E. (2009). Evangelical Teaching: Dr. Cumming”. The Essays of George Eliot. Ed. Nathan Sheppard. The Project Gutenberg. P-64. [online] Available: http://www.gutenberg.org/files/28289/28289-h/28289-h.htm\#citation64

Hadley, G. (2009). "Introduction.” Daniel Deronda. Oxford: Oxford University Press.

Haight, G. S. (1968). George Eliot: A Biography. New York and Oxford: Oxford University Press.

Haight, G.S. (1985). Selections from George Eliot's Letters. New Haven: Yale University Press.

Hardy, B. (1954)."The Moment of Disenchantment in George Eliot's Novels." The Review of English Studies, New Series, 5 254-264.

Hardy, B. (1970). Critical Essays on George Eliot. Barnes and Nobel: New York.

Ingham, P. (2003). The Language and Gender and Class: Transformation in Victorian. Routledge, London.

John R. R. and Jerry, H. (1985). “George Eliot's Illegitimate Children.” Nineteenth-Century Fiction 40:175-186.

John, P. M. (1980). “The Turn of George Eliot's Realism.” Nineteenth-Century Fiction, 35 171-192.

John, T. (1999). A Man's Place: Masculinity and the Middle-class Home in Victorian England. Yale University Press.

Knoepflmacher, U.C.(1975). "Middlemarch: An Avuncular View.” Nineteenth-Century Fiction 30 53-81.

Leonore, D. and Catherine, H. (2002) Family Fortunes: Men and Women of the English Middle Class. 1780-1850. rev. edn, London and New York.

McKnight, N. (ed.) (2011). Fathers in Victorian Fiction. Cambridge Scholars Publishing. 
Nelson C. (2007) Family Ties in Victorian England. Praeger Publishers.

Pell, N. (1982). “The Fathers’ Daughters in Daniel Deronda” Nineteenth-Century Fiction 36. 4 424-45.

Pinion, F. B. (1981). A George Eliot Companion. London: The Macmillan Press.

Sadoff, F. D. Monsters of Affection: Dickens, Eliot \& Bronte on Fatherhood. John Hopkins University Press, London. 1982.

Sanders, V. (2009). The Tragi-Comedy of Victorian Fatherhood. Cambridge University Press.

Tosh, J. (1999). A Man's Place: Masculinity and the Middle-class Home in Victorian England. Yale University Press.

Wilt, J. (1987). "He Would Come Back: The Fathers of Daughters in Daniel Deronda" Nineteenth-Century Literature $42.3313-338$.

Zwinger, L. (1991). Daughters, Fathers, and the Novel: The sentimental Romance of heterosexuality. Madison: University of Wisconsin Press. 